\title{
Breast cancer detection and survival among women with cosmetic breast implants: systematic review and meta-analysis of observational studies
}

\author{
(C) $(1) \Theta$ OPEN ACCESS
}

\author{
Eric Lavigne epidemiologist ${ }^{12}$, Eric J Holowaty adjunct professor ${ }^{3}$, Sai Yi Pan epidemiologist ${ }^{2}$, Paul \\ $\mathrm{J}$ Villeneuve senior research scientist ${ }^{34}$, Kenneth $\mathrm{C}$ Johnson adjunct professor ${ }^{5}$, Dean A Fergusson \\ senior scientist and director ${ }^{6}$, Howard Morrison director ${ }^{2}$, Jacques Brisson full professor ${ }^{1}$
}

${ }^{1}$ Centre de recherche du CHU de Québec, Faculté de médecine, Université Laval, Quebec, QC, Canada; ${ }^{2}$ Public Health Agency of Canada, Ottawa, ON, Canada; ${ }^{3}$ Dalla Lana School of Public Health, University of Toronto, Toronto, ON, Canada; ${ }^{4}$ Population Studies Division, Health Canada, Ottawa, ON, Canada; ${ }^{5}$ Department of Epidemiology and Community Medicine, University of Ottawa, Ottawa, ON, Canada; ${ }^{6}$ Clinical Epidemiology Program, Ottawa Hospital Research Institute, Ottawa, ON, Canada

\begin{abstract}
Objectives To evaluate whether the stage distribution among women diagnosed as having breast cancer differs between those who have received breast implants for cosmetic purposes and those with no implants and to evaluate whether cosmetic breast augmentation before the detection of breast cancer is a predictor of post-diagnosis survival.

Design Systematic review of observational studies with two meta-analyses.
\end{abstract}

Data sources Systematic search of the literature published before September 2012 conducted in Medline, Embase, Global health, CINAHL, IPAB, and PsycINFO.

Study selection Eligible publications were those that included women diagnosed as having breast cancer and who had had augmentation mammaplasty for cosmetic purposes.

Results The overall odds ratio of the first meta-analysis based on 12 studies was 1.26 (95\% confidence interval 0.99 to $1.60 ; P=0.058$; $\mathrm{I}^{2}=35.6 \%$ ) for a non-localized stage of breast cancer at diagnosis comparing women with implants who had breast cancer and women without implants who had breast cancer. The second meta-analysis, based on five studies, evaluated the relation between cosmetic breast implantation and survival. This meta-analysis showed reduced survival after breast cancer among women who had implants compared with those who did not (overall hazard ratio for breast cancer specific mortality $1.38,95 \%$ confidence interval 1.08 to 1.75$)$.

Conclusions The research published to date suggests that cosmetic breast augmentation adversely affects the survival of women who are subsequently diagnosed as having breast cancer. These findings should be interpreted with caution, as some studies included in the meta-analysis on survival did not adjust for potential confounders. Further investigations are warranted regarding diagnosis and prognosis of breast cancer among women with breast implants.

\section{Introduction}

Cosmetic breast augmentation has become increasingly popular. ${ }^{1}$ In the United States, for example, cosmetic breast augmentation was the most commonly performed cosmetic surgical procedure in 2011; 307000 surgeries were performed, ${ }^{2}$ an increase of approximately $800 \%$ compared with the early 1990s. Although breast augmentation is popular, controversies about the long term health effects of breast implants remain.

The weight of evidence from epidemiological studies indicates that cosmetic breast implants are not associated with increased risk of breast cancer. ${ }^{3-26}$ Concern remains, however, that implants may impair the ability to identify breast cancer at an early stage by mammography because cosmetic breast implants are radio-opaque, impairing the visualization of breast tissue with mammography and making detection of breast cancer at an early stage more difficult. ${ }^{47-29}$ Specialized radiographic techniques have been developed for women with breast implants to improve visualization, which involve displacing the implant posteriorly against the chest wall and pulling breast tissue over and in front of the implant. ${ }^{29-31}$ However, one third of the breast is still not adequately visualized despite such techniques, leading to an increase in false negative mammograms. ${ }^{28}$ An estimated one in eight US women will be diagnosed as having breast cancer at some time in their lives. ${ }^{32}$ Therefore, some women with breast implants will eventually develop breast cancer, which raises 
concerns about the possible effects of implants on detection of breast cancer.

Most studies that have evaluated the detection of breast cancer among women with cosmetic breast implants compared the stage distribution of breast cancer at diagnosis between women with and without implants. The findings from these studies have been inconsistent. For instance, some studies reported that women with breast augmentation may be more likely to be diagnosed as having advanced cancers, ${ }^{18} 273334$ whereas others have reported no such difference. ${ }^{81013151719-212535-43}$ These conflicting results may be explained by methodological problems within studies, as well as the small number of cases of incident breast cancer in these studies which limits statistical power to obtain significant results. In addition to the question of stage of breast cancer at diagnosis, no study to date has been able to establish that women with breast implants, although they may receive a diagnosis at a more advanced stage, have a poorer survival following diagnosis of breast cancer compared with women without implants, but these studies were also impaired by relatively low statistical power. ${ }^{810} 183439-41$ Better understanding of the detection of breast cancer and survival patterns following diagnosis of breast cancer among women with implants will aid in giving clear information on the consequences of breast augmentation surgery to these women and their physicians. The fact that implants may interfere with the early detection of breast cancer is particularly relevant and carries with it important clinical and public health implications.

Most recent reviews that summarized the evidence of the long term effects of cosmetic breast implants concluded that they were not associated with advanced breast cancers and nor was survival affected. ${ }^{9445}$ Although these papers provided a timely synthesis of the scientific literature on this question, they were not presented as systematic reviews and did not provide a quantitative meta-analysis of published studies. Through a systematic literature search, we have identified additional papers published in the past decades that were not captured by previous reviews, as well as three more recent publications, ${ }^{818} 34$ providing suitable data for a quantitative meta-analysis on the diagnosis and prognosis of breast cancer among augmented women.

Specifically, our objectives were to verify the stage distribution of breast cancer and post-diagnosis survival among women with cosmetic breast implants compared with women without implants by means of a systematic review and two meta-analyses in accordance with the meta-analysis of observational studies in epidemiology (MOOSE) reporting guidelines. ${ }^{46} \mathrm{We}$ also sought to identify sources of heterogeneity in risk estimates in the existing literature and to identify gaps in the current state of knowledge. This investigation is important to consolidate the existing knowledge on the long term effects of cosmetic breast implants.

\section{Methods}

\section{Search strategy}

To identify eligible studies published before September 2012, we applied a systematic literature search strategy to the following electronic databases: Medline, Embase, Global health, CINAHL, IPAB, and PsycINFO. We also searched the Cochrane Library's Database of Systematic Reviews. We used the following keywords and subject headings in combination to identify relevant articles in electronic databases: breast neoplasms AND (breast implants OR breast augmentation OR mammaplasty OR mammoplasty OR breast implantation OR breast prosthesis) AND (women without implants OR non augmented women) AND (delayed diagnosis OR prognosis OR survival OR delayed detection OR staging). We manually examined reference lists from retrieved articles $^{810131517-21252734-4347}$ and published reviews ${ }^{9} 16234$ to identify additional manuscripts. Eligible articles were original, peer reviewed, published studies. We reviewed abstracts from identified articles to assess eligibility. Additionally, as direct contact with experts has been shown to be an effective method of retrieving relevant articles, we surveyed international experts who published papers on detection of breast cancer among women with cosmetic breast implants and associated survival rate patterns to request any relevant published or unpublished scientific articles. ${ }^{48}$ The search was limited to French and English articles.

\section{Study eligibility}

Eligible publications (that is, case-control studies, cohort studies, or cross sectional studies) were those that included women diagnosed as having breast cancer and who had had antecedent augmentation mammaplasty for cosmetic purposes. The comparison group consisted of women diagnosed as having breast cancer who had had other common elective cosmetic surgeries or who were from the general female population.

Eligible publications for the evaluation of the association of breast implants with the stage distribution of breast cancer had to include the number of women with breast implants diagnosed as having breast cancer (exposed group) and women without implants diagnosed as having breast cancer (unexposed group) per stage of breast cancer at diagnosis or per status of nodal involvement, metastases, or both. We used measures of association describing the odds of having non-localized breast tumors (nodal involvement positivity, metastases to distant sites, or both) comparing the exposed breast cancer cases with the unexposed cases if they were provided in the paper. Otherwise, we calculated the crude odds ratios, their respective standard errors, and $95 \%$ confidence intervals from the contingency tables.

Publications eligible for the evaluation of breast implants and survival following diagnosis of breast cancer provided either hazard ratios comparing the mortality rate due to breast cancer after diagnosis between the exposed and unexposed group or provided Kaplan-Meier breast cancer specific survival curves graphically for women with breast cancer with and without implants. For these last studies, we estimated hazard ratios by using the spreadsheet provided by Tierney et $\mathrm{al},{ }^{49}$ based on published statistics provided in the manuscripts, and by extracting data directly from Kaplan-Meier survival curves by using recommended techniques for time to event meta-analysis. $^{50} 51$

When several publications were available for the same study group, we retained the most recent one for analysis. We excluded publications without a comparison group for the women with implants. We also excluded those that did not provide measures of association and did not provide crude numbers in contingency tables allowing calculation of measures of association regarding stage of breast cancer at diagnosis.

A certified librarian did the search, and two authors (EL and SYP) independently excluded studies at the first stage of evaluation for eligibility. The two authors discussed studies identified for a more detailed assessment on the basis of the abstract and title.

\section{Data abstraction}

Two authors (EL and SYP) independently extracted characteristics of studies and resolved any uncertainty through 
discussion. The characteristics extracted were source of data on implant, source of data on breast cancer diagnosis, source of data on mortality, assessment of stage of breast cancer, nodal involvement, type of comparison group, number of women with implants with breast cancer, number of women without implants with breast cancer, mean length of follow-up, average age at diagnosis of breast cancer, whether statistical adjustment for potential confounders was done (for example, adjusting for age at diagnosis, period of diagnosis) and results (cell counts, odds ratios, hazard ratios, and $95 \%$ confidence intervals). Adjusted estimates were always selected over unadjusted estimates when provided in the paper. We created a dichotomous variable for the exposure variable (presence of breast implants with breast cancer versus no implants with breast cancer) and for the outcome (stage distribution of breast cancer). Staging of breast cancer among the studies included principally the American Joint Committee on Cancer's tumor node metastasis (TNM) classification, ${ }^{52} 53$ without limiting the edition of the classification that was used, and the US National Cancer Institute's surveillance epidemiology and end results (SEER) summary stage system. ${ }^{54}$ For the purpose of consistency in the analyses, we excluded, when possible, ductal carcinoma in situ, lobular carcinoma in situ, and all other non-invasive breast cancers. We did this because several publications included in our meta-analyses excluded these cases on the basis of problems with data quality related to the reporting of in situ cancers.

Therefore, we considered only invasive breast cancers. Given the considerable variability across studies for the classification used for stage distribution of breast cancer, especially between the TNM classification and the SEER summary stage system, we dichotomized the response variable as non-localized breast cancer (regional or distant) versus localized breast cancer. We firstly chose this cut-off for clinical relevancy because localized breast tumors are potentially more curable than non-localized tumors and are associated with better survival rates. ${ }^{55}$

Additionally, we chose this cut-off for purposes of compatibility between the two cancer staging systems. Irrespective of the classification system, breast tumors that did not spread to regional lymph nodes or distant sites were considered to be localized tumors. Therefore, non-localized breast tumors were considered to be advanced or later stage breast cancers.

\section{Statistical analyses}

The statistical analyses, forest plots, and sensitivity, meta-regression, and publication bias analyses were produced with Stata software, release 12. Studies had to provide sufficient data for calculation of an effect size measure to be included in the quantitative analysis. We used a Dersimonian-Laird random effects model to derive a pooled effect across studies for the association between cosmetic breast implants and stage distribution of breast cancer. ${ }^{56}$ We used the random effects model because it accounts for variations between studies in addition to sampling error within studies. ${ }^{57}$ All analyses were conducted on the natural log scale. We calculated the summary odds ratio with $95 \%$ confidence interval from study specific adjusted odds ratios taken directly from the study or estimated as crude odds ratios from cell counts. We also took study specific confidence intervals directly from the study if reported or calculated them by using the corresponding standard error. We used a random effects model to calculate the summary hazard ratio for the association between cosmetic breast implants and survival. We calculated the pooled effect from study specific hazard ratios that were obtained directly from the study or calculated from survival curves. To quantify the degree of heterogeneity across studies, we used Cochrane's Q test and the Higgins I $^{2}$ statistic with $95 \%$ confidence intervals. ${ }^{58} 59$ This last statistic indicates the proportion of the variance attributable to between study variability. ${ }^{59}$

We also did sensitivity analyses to identify studies contributing disproportionately to the observed heterogeneity. We did this by omitting each study one by one to analyze the influence of individual studies on the summary estimate, ${ }^{60}$ and also by comparing the studies for which in situ breast cancers could not be excluded with those studies for which we excluded in situ breast cancers. We also made a visual inspection by using the Galbraith plot to detect possible outlier studies that have an excessive influence on the overall estimate. ${ }^{61}{ }^{62}$ To identify potential sources of heterogeneity, we examined only the association between cosmetic breast implants and stage distribution of breast cancer, as we had too few studies to examine sources of heterogeneity for the association between cosmetic breast implants and survival. We did this by calculating a summary odds ratio across strata of factors selected a priori as potentially related to quality of study and that were present enough across studies to allow stratification. These factors included source of comparison group (other cosmetic surgery controls versus population based controls), source of exposure data (plastic surgeons' records versus medical records), breast cancer staging system (TNM staging versus SEER staging), and statistical adjustment of the odds ratio for potential confounders (adjusted versus unadjusted). We also evaluated the effect of these factors on heterogeneity by using random effects meta-regression models. This investigates how a categorical or continuous characteristic at the study level is associated with the effect estimate in the meta-analysis. ${ }^{60}$ The outcome variable in the meta-regression models in this study is the odds ratio and the explanatory variables, also called potential effect modifiers, are the factors selected a priori as potentially related to study quality. We also evaluated the year of publication of each study as a potential source of heterogeneity as a continuous variable in a meta-regression model. We assessed publication bias for the association between cosmetic breast implants and stage distribution of breast cancer by using a funnel plot and Egger's test. ${ }^{63} \mathrm{We}$ did not have enough studies to examine heterogeneity and publication bias for the association between cosmetic breast implants and survival.

\section{Results}

We identified 282 unique papers after searching Medline, Embase, Global health, CINAHL, IPAB, and PsycINFO. Of these, 22 publications ( $n=28924$ women) met eligibility for the evaluation of stage distribution of breast cancer and breast implants, and seven publications ( $\mathrm{n}=18026$ women) met eligibility criteria for the evaluation of survival following breast cancer diagnosis and breast implants (fig $1 \Downarrow$ ). No papers were identified after searching the Cochrane Library's Database of Systematic Reviews, through further investigation of previous reviews, or through manual examination of references or querying of the experts. No unpublished scientific articles were identified through expert consultations. A quality assessment scale also showed that publications that met eligibility were of acceptable quality to be included in these meta-analyses (supplemental file in web appendix). ${ }^{64}$

\section{Breast implants and stage distribution of breast cancer}

Twelve studies, all cross sectional in their design, provided sufficient data to be included in a meta-analysis to evaluate the association between cosmetic breast implants and stage 
distribution of breast cancer. Table $1 \Downarrow$ shows characteristics of the 12 studies meeting the inclusion criteria and selected for the quantitative analysis. Most of these were published after 2000 and were conducted in the United States. The remainder were conducted in northern Europe or Canada. The other 10 papers were all excluded because they overlapped with more recent publications with an extended follow-up of the same study group.

Figure $2 \Downarrow$ shows the results of the meta-analysis. The size of each box indicates the relative weight of each publication in the meta-analysis, and the bars show the $95 \%$ confidence intervals. Based on the 12 studies, the summary odds ratio with the random effects model was 1.26 (95\% confidence interval 0.99 to 1.60 ; $\mathrm{P}=0.058$ ) for a non-localized stage of breast cancer at diagnosis comparing women with breast cancer who had implants with women with breast cancer who did not have implants. Moderate heterogeneity was present $\left(\mathrm{Q}=17.07, \mathrm{P}=0.11, \mathrm{I}^{2}=35.6 \%\right)$.

\section{Sensitivity analysis and publication bias}

Sensitivity analyses showed that one publication, Clark et al, ${ }^{38}$ accounted for all the observed heterogeneity. When we included all 12 studies in the analysis, $\mathrm{I}^{2}$ was $35.6 \%$. $\mathrm{I}^{2}$ was $0 \%$ when this paper was removed, suggesting that it had an important influence on the overall estimate. ${ }^{60}$ Additionally, the Galbraith plot showed that this study contributed disproportionately to the observed heterogeneity (data not shown). The summary odds ratio using the random effects model when that study was excluded was 1.42 (1.19 to 1.68). The omission of all other studies separately resulted in random variation around the overall estimate for the remaining 11 studies. Moreover, sensitivity analyses showed that the omission of five studies for which in situ breast cancers could not be excluded resulted in an overall estimate similar to the one mentioned above (odds ratio $1.40,1.10$ to 1.78)..$^{8} 17384043$ The Egger's test did not indicate the presence of publication bias $(\mathrm{P}=0.16)$. Additionally, a visual inspection of the funnel plot did not suggest publication bias as the studies were distributed symmetrically about the combined effect size (data not shown).

\section{Meta-regression analysis}

Table $2 \Downarrow$ shows results with stratification by variables potentially related to quality of study. Overall odds ratios stratified by these variables did not produce meaningful differences, except for the studies that provided adjusted estimates for relevant covariates such as age at diagnosis of breast cancer and calendar period of diagnosis (odds ratio $1.51,1.18$ to 1.92). In comparison, studies that did not provide adjusted estimates yielded an overall odds ratio of 1.07 (0.74 to 1.55). In addition, the summary effect for the three studies that compared women with cosmetic breast implants with women who received other elective cosmetic surgery was 1.53 (0.89 to 2.64) and the odds ratio when comparing women with implants and the general female population was 1.16 (0.88 to 1.53$)$. Table $2 \Downarrow$ also shows the statistical significance of meta-regression models. Inclusion of these variables one at a time in a random effects meta-regression model did not reach statistical significance.

\section{Breast implants and survival}

Table $3 \Downarrow$ shows a description of the five publications, all with a cohort design, included in the meta-analysis for the association between cosmetic breast implants and breast cancer specific survival following diagnosis of breast cancer. The two papers that were excluded overlapped with a more recent publication.
Figure $3 \Downarrow$ shows the results of the meta-analysis of cosmetic breast implants and breast cancer specific survival. The overall hazard ratio comparing the breast cancer specific mortality after diagnosis between women with breast cancer who had implants and women with breast cancer who did not have implants was $1.38(1.08$ to 1.75$)$, with no heterogeneity observed $(\mathrm{Q}=3.35$, $\left.\mathrm{P}=0.50, \mathrm{I}^{2}=0.0 \%\right)$. The Egger's test did not indicate the presence of publication bias $(\mathrm{P}=0.84)$. Omission of the publication that assessed overall mortality resulted in random variation around the overall estimate of the four remaining studies. We did not have enough studies to do a meta-regression.

\section{Discussion}

This systematic review suggests that women with cosmetic breast implants have later stage tumors at diagnosis of breast cancer. In our second meta-analysis, the results show a higher risk of breast cancer specific mortality among women with breast cancer who have implants compared with women with breast cancer without implants. Nevertheless, the overall estimate should still be interpreted with caution because this meta-analysis included a relatively small number of studies. Of concern, three of five studies had unadjusted hazard ratios (not adjusted for age at diagnosis, or period of diagnosis) and all five studies were unadjusted for other potential confounding factors such as body mass index, which could translate into a biased estimate of the summary hazard ratio. A lack of adjustment for body mass index has previously been shown to lead to underestimation of the association between cosmetic breast implants and breast cancer mortality. ${ }^{18}$ Moreover, one study included in this meta-analysis assessed overall mortality rather than breast cancer specific mortality, ${ }^{39}$ which could have biased our summary estimate towards the null. The small number of studies and insufficient amount of follow-up time in these studies are suspected to limit statistical power to clearly evaluate survival rate patterns among augmented women. Given the limited evidence, no conclusion regarding breast cancer specific survival can be drawn and continued follow-up to further evaluate this question is particularly relevant.

\section{Possible explanations for findings}

The finding of later stage tumors at diagnosis of breast cancer in women with implants can be explained by multiple mechanisms, the first being that both silicone and saline implants create radio-opaque shadows on mammograms, which impair the visualization of breast tissue. ${ }^{65}$ The amount of parenchymal breast tissue obscured at mammography by the implant is known to be between $22 \%$ and $83 \% .{ }^{66}$ Insufficient compression of the breast to visualize the parenchyma and the production of implant related artifacts on the film can also make interpretation of mammographic examinations difficult in women with augmented breasts. ${ }^{28} 29$ Additionally, capsular contracture, which develops in about $15-20 \%$ of women with implants, has been shown to reduce mammographic sensitivity by $30-50 \% .^{65}$ Furthermore, specific characteristics of breast implants might affect the detection of breast cancer. ${ }^{67}$ Specifically, implants placed under the breast glands (subglandular placement), because of their proximity with breast tissue, are suspected to obstruct mammographic visualization of the breast more than those with submuscular placement. ${ }^{43}$ However, to date, only one study has been able to evaluate the stage distribution of breast cancer according to implant placement. ${ }^{18}{ }^{34}$ Results from this study were inconclusive.

Despite the fact that implant displacement techniques are widely used with mammography, studies suggest that breast tissue is 
still not adequately visualized. ${ }^{85}$ Recent reports suggest that magnetic resonance imaging of the breast may be a helpful diagnostic tool for women with breast implants; it allows examination of all breast tissue surrounding the implant, ${ }^{68} 69$ and so has greater sensitivity than mammography. ${ }^{70}$ However, insufficient evidence exists to support the use of magnetic resonance imaging in the diagnosis and prognosis of breast cancer, which warrants further research.

Stratification and meta-regression models showed that no potential factors seem to unduly affect the results of the study. When we calculated a summary effect for the three studies that used women who had received other elective cosmetic surgery (chemical peel or dermabrasion, coronal brow lift, otoplasty, rhinoplasty, rhytidectomy, or blepharoplasty) as the comparison group, we observed a stronger association than the one obtained when the general female population was used as the comparison group. Women with other cosmetic surgery are recognized in the scientific literature as being a more appropriate comparison group when studying the health effects associated with cosmetic breast implants, because they tend to be more similar in terms of sociodemographic and lifestyle factors as well as health consciousness than are women in the general population. ${ }^{71}{ }^{72} \mathrm{~A}$ previous study conducted in the United States showed no significant differences with respect to family income between women with cosmetic breast implants and women with other cosmetic surgery, which supports the notion that both groups are of similar socioeconomic status. ${ }^{71}$ For example, women seeking cosmetic surgeries could have better screening and self examination practices than women in the general female population, which would translate into higher chances of a breast tumor being diagnosed after screening mammography if one is present. This suggests that using other women with cosmetic surgery would be more adequate in terms of controlling for potential confounders. Moreover, studies with adjustment for confounding factors such as the age of breast cancer at diagnosis yielded statistically significant effects that were stronger than those without adjustment. One study showed that a lack of adjustment for the age at which breast cancer was diagnosed underestimates the measure of association. ${ }^{34}$ This outlines the importance of providing adjusted estimates. In meta-regression models, we were not able to detect the modifying effect of the type of comparison group and the adjustment for cofactors, but a lack of statistical power due to the small number of studies may explain why the above differences in odds ratios are not statistically significant.

The long term presence of cosmetic breast implants has been hypothesized to cause atrophy, thinning, and compression of the breast parenchyma, which may facilitate the detection of palpable breast tumors on physical examination. ${ }^{8101720}$ The breast implants could serve as a base against which the mass may be more likely to be differentiated. ${ }^{73}$ This suggests that tumors of equal size may be more easily palpated in patients with implants, especially for implants placed in the subglandular position, ${ }^{66}$ and this may compensate somewhat for the potential impairment of mammography. However, very few studies have evaluated this question, providing no conclusive results. ${ }^{10} 1720$ Furthermore, the fact that women with implants present more often with palpable tumors could also be because of the smaller native breast volumes making tumors more pronounced with palpation. $^{38}$

\section{Limitations of study}

Our study has several limitations specific to our analysis and to the different methods used across studies. For instance, certain studies used in both meta-analyses included cases of in situ breast cancer because we were not able to exclude them on the basis of the limited information available in the papers. ${ }^{8} 17384043$ This could have resulted in a non-differential misclassification bias of the outcome variable. One study, by Clark et al, ${ }^{38}$ was responsible for all observed heterogeneity in the analysis of stage distribution of breast cancer at diagnosis. We believe that the results of this publication may be affected by a selection bias, which is supported by the quality assessment scale (supplemental file in web appendix). Moreover, a previous publication also raised the concern that the results of the study by Clark et al may have been influenced by a selection bias. ${ }^{39}$ Pooling results from several observational studies has the advantage of increasing statistical power but does not increase internal validity. Misclassification bias, selection bias, and assessment of confounding affecting individual studies will also affect the meta-analyses. Misclassification biases within each study could also be a factor affecting study specific measures of association and consequently our pooled effect. For example, the identification of deaths from breast cancer could be affected by data quality problems such as a misclassification of the cause of death. This could result in biased estimates of breast cancer specific survival, resulting in an underestimation of our pooled effect. Although we have evaluated the quality of the studies with an assessment scale, ${ }^{64}$ no threshold scores were available to distinguish between "good" and "poor" quality studies, which could limit our results as we may have included studies of poorer quality in our analyses. Another limitation of our study could be related to the methods used to pool the hazard ratios from available data in each study, which may have underestimated the variance of the estimates.

\section{Conclusions and implications}

Our results should be interpreted with caution, considering the current gaps and limitations in the available literature. The accumulating evidence suggests that women with cosmetic breast implants who develop breast cancer have an increased risk of being diagnosed as having non-localized breast tumors more frequently than do women with breast cancer who do not have implants. Moreover, current evidence also suggests that cosmetic breast implants adversely affect breast cancer specific survival following the diagnosis of such disease. Further investigations are warranted into the long term effects of cosmetic breast implants on the detection and prognosis of breast cancer, adjusting for potential confounders.

We thank Melanie Weger, reference librarian at Health Canada, for doing the search of the scientific literature and Anne Rosenberg for sharing data on a previous publication.

Contributors: EL, JB, and EJH were responsible for study concept and design and supervised the study. EL and SYP acquired the data, which was analyzed and interpreted by EL, JB, EJH, SYP, PJV, KCJ, DAF, and HM. EL drafted the manuscript, which was critically revised for important intellectual content by EL, JB, EJH, SYP, PJV, KCJ, DAF, and HM. EL did the statistical analysis with supervision from JB, EJH, and DAF. EL is the guarantor.

Funding: This work was supported through scholarship grants by the Unité de Recherche en Santé des Populations, Cancer Care Ontario, and the Public Health Agency of Canada.

Competing interests: All authors have completed the ICMJE uniform disclosure form at www.icmje.org/coi_disclosure.pdf (available on request from the corresponding author) and declare: no support from any organization for the submitted work; no financial relationships with any organization that might have an interest in the submitted work in the previous three years; no other relationships or activities that could appear to have influenced the submitted work. 


\section{What is already known on this topic}

Cosmetic breast implants have become increasingly popular in recent decades Breast implants are radio-opaque at mammography, impairing the visualization of breast tissue Studies have raised the concern that breast implants may impair the ability to identify breast cancer at an early stage when survival is generally more favorable

\section{What this study adds}

On the basis of studies published to date, cosmetic breast augmentation seems to adversely affect the survival experience of women who are subsequently diagnosed as having breast cancer

\section{Ethical approval: Not required.}

Data sharing: No additional data available.

1 Love S, Lindsey K. Variations in development: Dr. Susan Love's breast book. Perseus Publishing, 2000

2 About.com. 2011 top five cosmetic surgical procedures. 2012. http://plasticsurgery.about. com/od/Plastic_Surgery_Statistics/tp/2011-Top-Five-Cosmetic-Surgical-Procedures.htm.

3 Deapen DM, Pike MC, Casagrande JT, Brody GS. The relationship between breast cancer and augmentation mammaplasty: an epidemiologic study. Plast Reconstr Surg 1986;77:361-8.

4 Silverstein MJ, Handel N, Gamagami P. The effect of silicone-gel-filled implants on mammography. Cancer 1991:68(suppl 5):1159-63.

5 Schumann D. Health risks for women with breast implants. Nurse Pract 1994;19(7):19-30. Lipworth L, Tarone RE, Friis S, Ye W, Olsen JH, Nyren O, et al. Cancer among Scandinavian women with cosmetic breast implants: a pooled long-term follow-up study. Int J Cancer 2009;124:490-3.

7 McIntosh SA, Horgan K. Augmentation mammoplasty: effect on diagnosis of breast cancer. $J$ Plast Reconstr Aesthet Surg 2008:61:124-9.

8 Handel $\mathrm{N}$. The effect of silicone implants on the diagnosis, prognosis, and treatment of breast cancer. Plast Reconstr Surg 2007;120(suppl 1):81-93S.

9 Deapen DM. Breast implants and breast cancer: a review of incidence, detection, mortality, and survival. Plast Reconstr Surg 2007;120(suppl 1):70-80S.

10 Handel N, Silverstein MJ. Breast cancer diagnosis and prognosis in augmented women. Plast Reconstr Surg 2006;118:587-93.

11 Deapen DM, Hirsch EM, Brody GS. Cancer risk among Los Angeles women with cosmetic breast implants. Plast Reconstr Surg 2007;119:1987-92.

12 Mclaughlin JK, Lipworth L, Fryzek JP, Weimin Y, Tarone RE, Nyren O. Long-term cance risk among Swedish women with cosmetic breast implants: an update of a nationwide study. J Natl Cancer Inst 2006;98:557-60.

13 Tuli R, Flynn RA, Brill KL, Sabol JL, Usuki KY, Rosenberg AL. Diagnosis, treatment, and management of breast cancer in previously augmented women. Breast $J$ 2006;12:343-8.

14 Brisson J, Holowaty EJ, Villeneuve PJ, Xie L, Ugnat A, Latulippe L, et al. Cancer incidence in a cohort of Ontario and Quebec women having bilateral breast augmentation. Int $J$ Cancer 2005;118:2854-62.

15 Friis S, Holmich LR, Mclaughlin JK, Kjøller K, Fryzek JP, Henriksen TF, et al. Cancer risk among Danish women with cosmetic breast implants. Int J Cancer 2006;118:998-1003.

16 Meunier A, Tristant H, Sinna R, Delay E. [Mammary implants and breast cancer] [French]. Ann Chir Plast Esthet 2005;50:595-604.

17 Jakub JW, Ebert MD, Cantor A, Gardner M, Reintgen DS, Dupont EL, et al. Breast cancer in patients with prior augmentation: presentation stage, and lymphatic mapping. Plas Reconstr Surg 2004;114:1737-42.

18 Lavigne E, Holowaty EJ, Pan SY, Xie L, Villeneuve PJ, Morrison H, et al. Do breast implants adversely affect prognosis among those subsequently diagnosed with breast cancer? Findings from an extended follow-up of a Canadian cohort. Cancer Epidemio Biomarkers Prev 2012;21:1868-76.

19 Pukkala E, Boice,JD Jr, Hovi SL, Hemminki E, Asko-Seljavaara S, Keskimäki I, et al. Incidence of breast cancer and other cancers among Finnish women with cosmetic breas implants, 1970-1999. J Long Term Eff Med Implants 2002;12:251-3.

20 Skinner KA, Silberman H, Dougherty W, Gamagami P, Waisman J, Sposto R, et al. Breast cancer after augmentation mammoplasty. Ann Surg Oncol 2001;8:138-44.

21 Brinton LA, Lubin F, Burich MC, Colton T, Brown SL, Hoover RN. Breast cancer following augmentation mammoplasty (United States). Cancer Causes Control 2000;11:819-27.

22 Mellemkjaer L, Kjøller K, Friis S, Mclaughlin JK, Høgsted C, Winther JF, et al. Cancer occurrence after cosmetic breast implantation in Denmark. Int J Cancer 2000:88:301-6.

23 Hoshaw SJ, Klein PJ, Clark BD, Cook RR, Perkins LL. Breast implants and cancer: causation, delayed detection, and survival. Plast Reconstr Surg 2001;107:1393-408.

24 Mclaughlin JK, Nyren O, Blot WJ, Yin L, Josefsson S, Fraumeni JF Jr, et al. Cancer risk among women with cosmetic breast implants: a population based cohort study in Sweden J Natl Cancer Inst 1998;90:156-8.

25 Brinton LA, Malone KE, Coates RJ, Schoenberg JB, Swanson CA, Daling JR, et al. Breas enlargement and reduction: results from a breast cancer case-control study. Plast Reconstr Surg 1996;97:269-75

26 Malone KE, Stanford JL, Daling JR, Voigt LF. Implants and breast cancer. Lancet 1992;339:1365.

27 Silverstein MJ, Handel N, Gamagami P, Waisman JR, Gierson ED, Rosser RJ, et al. Breast cancer in women after augmentation mammoplasty. Arch Surg 1988;123:681-5.

28 Handel N, Silverstein MJ, Gamagami P, Jensen JA, Collins A. Factors affecting mammographic visualization of the breast after augmentation mammaplasty. JAMA 1992;268:1913-7.

29 Fajardo LL, Harvey JA, McAleese KA, Roberts CC, Granstrom P. Breast cancer diagnosis in women with subglandular silicone gel-filled augmentation implants. Radiology 1995;194:859-62.

30 Hayes H Jr, Vandergrift J, Diner WC. Mammography and breast implants. Plast Reconstr Surg 1988;82:1-8.

31 Eklund GW, Busby RC, Miller SH, Job JS. Improved imaging of the augmented breast. AJR Am J Roentgenol 1988;151:469-73.
32 Howlader N, Noone AM, Krapcho M, Neyman N, Aminou R, Waldron W, et al. SEER cancer statistics review, 1975-2009 (vintage 2009 populations). National Cancer Institute, 2012.

33 Silverstein MJ, Handel N, Gamagami P, Waisman E, Gierson ED. Mammographic measurements before and after augmentation mammaplasty. Plast Reconstr Surg 1990;86:1126-30

34 Xie L, Brisson J, Holowaty EJ, Vileneuve PJ, Mao Y. The influence of cosmetic breast augmentation on the stage distribution and prognosis of women subsequently diagnosed with breast cancer. Int J Cancer 2010;126:2182-90.

35 Deapen DM, Brody GS. Augmentation mammaplasty and breast cancer: a 5-year update of the Los Angeles study. Plast Reconstr Surg 1992;89:660-5.

36 Deapen DM, Bernstein L, Brody GS. Are breast implants anticarcinogenic? A 14-year follow-up of the Los Angeles study. Plast Reconstr Surg 1997;99:1346-53.

37 Friis S, Mclaughlin JK, Mellemkjaer L. Breast implants and cancer risk in Denmark. Int J Cancer 1997;714:956-8

38 Clark CP, Peters GN, O'Brien KM. Cancer in the augmented breast: diagnosis and prognosis. Cancer 1993;72:2170-4.

39 Hölmich LR, Mellemkjaer L, Gunnarsdóttir KA, Tange UB, Krag C, Møller S, et al. Stage of breast cancer at diagnosis among women with cosmetic breast implants. Br J Cancer 2003;88:832-8.

40 Birdsell DC, Jenkins $\mathrm{H}$, Berkel H. Breast cancer diagnosis and survival in women with and without breast implants. Plast Reconstr Surg 1993;92:795-800.

41 Deapen DM, Hamilton A, Bernstein L, Brody GS. Breast cancer stage at diagnosis and survival among patients with prior breast implants. Plast Reconstr Surg 2000;105:535-40.

42 Miglioretti DL, Rutter CM, Celler BM, Cutter G, Barlow WE, Rosenberg R, et al. Effect of breast augmentation on the accuracy of mammography and cancer characteristics. JAMA 2004;291:442-50

43 Cahan AC, Ashikari R, Pressman P, Cody H, Hoffman S, Sherman JE. Breast cancer after breast augmentation with silicone implants. Ann Surg Oncol 1995;2:121-5.

44 McLaughlin JK, Lipworth L, Murphy DK, Walker PS. The safety of silicone gel-filled breast implants: a review of the epidemiologic evidence. Ann Plast Surg 2007;59:569-80.

45 McIntosh SA, Horgan K. Breast cancer following augmentation mammoplasty-a review of its impact on prognosis and management. J Plast Reconstr Aesthet Surg 2007;60:1127-35

46 Stroup DF, Berlin JA, Morton SC, Olkin I, Williamson GD, Rennie D, et al. Meta-analysis of observational studies in epidemiology: a proposal for reporting. JAMA 2000;283:2008-12.

47 Silverstein MJ, Gierson ED, Gamagami P, Handel N, Waisman JR. Breast cancer diagnosis and prognosis in women augmented with silicone gel-filled implants. Cancer 990;66:97-101.

48 McManus RJ, Wilson S, Delaney BC, Fitzmaurice DA, Hyde CJ, Tobias RS, et al. Review of the usefulness of contacting other experts when conducting a literature search for systematic reviews. BMJ 1998;317:1562-3.

49 Tierney JF, Stewart LA, Ghersi D, Burdett S, Sydes MR. Practical methods for incorporating summary time-to-event data into meta-analysis. Trials 2007;8:16.

50 Williamson PR, Tudur Smith C, Hutton JL, Marson AG. Aggregate data meta-analysis with time-to-event outcomes. Stat Med 2002;21:3337-51.

51 Parmar MK, Torri V, Stewart L. Extracting summary statistics to perform meta-analyses of the published literature for survival endpoints. Stat Med 1998;17:2815-34.

52 American Joint Commission on Cancer. AJCC cancer staging manual. 5th ed. Springer, 1997.

53 American Joint Commission on Cancer. AJCC cancer staging manual.6th ed. Springer, 2002.

54 Shambaugh EM, Weiss MA, Axtell LM, eds. Summary staging guide for the cancer surveillance, epidemiology and end results reporting (SEER) program. 1st ed. National Institutes of Health, 1977.

55 Carlson RW, Allred DC, Anderson BO, Burstein HJ, Carter WB, Edge SB, et al. Breast cancer: noninvasive and special situations. J Natl Compr Canc Netw 2010;8:1182-207.

56 Dersimonian R, Laird N. Meta-analysis in clinical trials. Control Clin Trials 1986;7:177-88.

57 Littell J, Corcoran J, Pillai V. Systematic review and meta-analysis. Oxford University Press, 2008.

58 Cochran WG. The combination of estimates from different experiments. Biometrics 1954;10:101-29.

59 Higgins JP, Thompson SG. Quantifying heterogeneity in a meta-analysis. Stat Med 2002;21:1539-58

60 Borenstein M, Hedges L, Higgins J, Rothstein H. Introduction to meta-analysis. John Wiley \& Sons, 2009

61 Galbraith RF. Graphical display of estimates having differing standard errors. Technometrics 1988;30:271-81.

62 Galbraith RF. A note on graphical presentation estimated odds ratios from several clinical trials. Stat Med 1988;7:889-94.

63 Egger M, Davey Smith G, Schneider M, Minder C. Bias in meta-analysis detected by a simple, graphical test. BMJ 1997;315:629-34.

64 Ottawa Hospital Research Institute. The Newcastle-Ottawa Scale (NOS) for assessing the quality of nonrandomised studies in meta-analyses. www.ohri.ca/programs/clinical epidemiology/oxford.asp.

65 Tang SS, Gui GP. A review of the oncologic and surgical management of breast cancer in the augmented breast: diagnostic, surgical and surveillance challenges. Ann Surg Oncol 2011;18:2173-81. 
66 Smalley SM. Breast implants and breast cancer screening. J Midwifery Womens Health 2003:48:329-35.

67 Sarwer DB, Brown GK, Evans DL. Cosmetic breast augmentation and suicide. Am J Psychiatry 2007;164:1006-13

68 Uematsu T. Screening and diagnosis of breast cancer in augmented women. Breast Cancer 2008;15:159-64

69 Juanpere S, Perez E, Huc O, Motos N, Pont J, Pedraza S. Imaging of breast implants-a pictorial review. Insights Imaging 2011;2:653-70.

70 Orel SG, Schnall MD. MR imaging of the breast for the detection, diagnosis, and staging of breast cancer. Radiology 2001;220:13-30.

71 Brinton LA, Brown SL, Colton T, Burich MC, Lubin J. Characteristics of a population of women with breast implants compared with women seeking other types of plastic surgery. Plast Reconstr Surg 2000;105:919-29.

72 Kjoller K, Holmich LR, Fryzek JP, Jacobsen PH, Friis S, McLaughlin JK, et al. Characteristics of women with cosmetic breast implants compared with women with other types of cosmetic surgery and population-based controls in Denmark. Ann Plast Surg 2003;50:6-12.

73 Cunningham B. Breast cancer diagnosis and prognosis in augmented women-discussion. Plast Reconstr Surg 2006;118:587-93.

Accepted: 05 April 2013

\section{Cite this as: BMJ 2013;346:f2399}

This is an Open Access article distributed in accordance with the Creative Commons Attribution Non Commercial (CC BY-NC 3.0) license, which permits others to distribute, remix, adapt, build upon this work non-commercially, and license their derivative works on different terms, provided the original work is properly cited and the use is non-commercial. See: http://creativecommons.org/licenses/by-nc/3.0/. 


\section{Tables}

Table 1| Characteristics of 12 studies selected for quantitative analysis to evaluate association between cosmetic breast implants and stage distribution of breast cancer at diagnosis

\begin{tabular}{|c|c|c|}
\hline $\begin{array}{l}\text { First author, } \\
\text { country, } \\
\text { year }\end{array}$ & $\begin{array}{l}\text { Source of data } \\
\text { on implants }\end{array}$ & $\begin{array}{l}\text { Source of } \\
\text { data on } \\
\text { breast } \\
\text { cancer }\end{array}$ \\
\hline $\begin{array}{l}\text { Lavigne, } \\
\text { Canada, } \\
2012 \ddagger^{18}\end{array}$ & $\begin{array}{l}\text { Plastic } \\
\text { surgeons' } \\
\text { records, } \\
\text { hospital } \\
\text { discharge data }\end{array}$ & $\begin{array}{l}\text { Canadian } \\
\text { Cancer } \\
\text { Registry, } \\
\text { medical } \\
\text { records }\end{array}$ \\
\hline
\end{tabular}

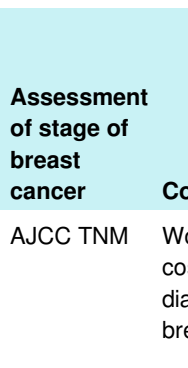

$\begin{array}{ll} & \begin{array}{l}\text { Women with } \\ \text { breast implants } \\ \text { with breast }\end{array} \\ \text { Comparison group } & \text { cancer }\end{array}$

\begin{tabular}{lccc} 
& \multicolumn{3}{c}{$\begin{array}{c}\text { Average } \\
\text { age at } \\
\text { breast }\end{array}$} \\
$\begin{array}{l}\text { Women without } \\
\text { cancer } \\
\text { breast implants } \\
\text { with breast cancer }\end{array}$ & $\begin{array}{c}\text { Mean } \\
\text { length of } \\
\text { follow-up } \\
\text { (years) }\end{array}$ & $\begin{array}{c}\text { diagnosis } \\
\text { (years) } \dagger\end{array}$ & Adjustment \\
\hline 444 women: & 16.1 & 52.3 & Adjusted for
\end{tabular}
diagnosed as having non-localized 162; non-localized 132; 1-32) 25-85) diagnosis, breast cancer unknown 52 unknown 46 period of diagnosis, and province of

\begin{tabular}{|c|c|c|c|c|c|c|c|c|c|}
\hline $\begin{array}{l}\text { Handel, } \\
\text { United } \\
\text { States, } \\
2007 \S^{8} \\
\end{array}$ & $\begin{array}{l}\text { Medical } \\
\text { records }\end{array}$ & $\begin{array}{l}\text { Medical } \\
\text { records }\end{array}$ & AJCC TNM & $\begin{array}{l}\text { Women treated for } \\
\text { breast cancer at } \\
\text { same clinics as } \\
\text { implant patients }\end{array}$ & $\begin{array}{l}128 \text { women: } \\
\text { localized } 69 ; \\
\text { non-localized } 59\end{array}$ & $\begin{array}{l}3795 \text { women: } \\
\text { localized } 2467 ; \\
\text { non-localized } 1328\end{array}$ & Unknown & $\begin{array}{l}46.8 \\
\text { (range } \\
29-71 \text { ) }\end{array}$ & None \\
\hline $\begin{array}{l}\text { Tuli, United } \\
\text { States, } \\
2006 \ddagger^{13}\end{array}$ & $\begin{array}{l}\text { Medical } \\
\text { records }\end{array}$ & $\begin{array}{l}\text { Medical } \\
\text { records }\end{array}$ & AJCC TNM & $\begin{array}{l}\text { Women diagnosed } \\
\text { as having breast } \\
\text { cancer at same } \\
\text { hospital as implant } \\
\text { patients }\end{array}$ & $\begin{array}{l}12 \text { women: in situ } \\
2 \text {; localized } 5 ; \\
\text { non-localized } 4 \text {; } \\
\text { unknown } 1\end{array}$ & $\begin{array}{l}3565 \text { women: in situ } \\
809 \text {; localized 401; } \\
\text { non-localized 202; } \\
\text { unknown } 2153\end{array}$ & $\begin{array}{c}12.6 \\
\text { (range } \\
1-31 \text { ) }\end{array}$ & $\begin{array}{c}49.2 \\
\text { (range } \\
31-63 \text { ) }\end{array}$ & $\begin{array}{l}\text { Adjusted for } \\
\text { age at } \\
\text { diagnosis }\end{array}$ \\
\hline $\begin{array}{l}\text { Friis, } \\
\text { Denmark, } \\
2005 \S^{15}\end{array}$ & $\begin{array}{l}\text { Plastic } \\
\text { surgeons' } \\
\text { records, } \\
\text { hospital } \\
\text { records }\end{array}$ & $\begin{array}{l}\text { Hospital } \\
\text { records, } \\
\text { Danish } \\
\text { cancer } \\
\text { registry }\end{array}$ & SEER EOD & $\begin{array}{l}\text { Women with other } \\
\text { cosmetic surgery } \\
\text { diagnosed as having } \\
\text { breast cancer }\end{array}$ & $\begin{array}{l}31 \text { women: } \\
\text { localized 17; } \\
\text { non-localized } 14\end{array}$ & $\begin{array}{l}30 \text { women: } \\
\text { localized 13; } \\
\text { non-localized 15; } \\
\text { unknown } 2\end{array}$ & $\begin{array}{c}\text { Range } \\
0-30\end{array}$ & Unknown & None \\
\hline $\begin{array}{l}\text { Miglioretti, } \\
\text { United } \\
\text { States, 2004 }\end{array}$ & $\begin{array}{l}\text { Mammography } \\
\text { registries }\end{array}$ & $\begin{array}{l}\text { State cancer } \\
\text { registries }\end{array}$ & AJCC TNM & $\begin{array}{l}\text { Women diagnosed } \\
\text { as having breast } \\
\text { cancer in same } \\
\text { mammography } \\
\text { registry as implant } \\
\text { patients }\end{array}$ & $\begin{array}{l}137 \text { women: in situ } \\
21 \text {; localized } 78 ; \\
\text { non-localized } 36 ; \\
\text { unknown } 2\end{array}$ & $\begin{array}{l}685 \text { women: in situ } \\
122 \text {; localized } 388 ; \\
\text { non-localized 152; } \\
\text { unknown } 23\end{array}$ & Unknown & Unknown & $\begin{array}{l}\text { Matched (5:1) } \\
\text { by age at } \\
\text { diagnosis, } \\
\text { ethnicity, } \\
\text { mammography } \\
\text { examination } \\
\text { within } 2 \text { years } \\
\text { of diagnosis } \\
\text { (yes/no), first or } \\
\text { subsequent } \\
\text { mammogram, } \\
\text { and } \\
\text { mammography } \\
\text { registry }\end{array}$ \\
\hline $\begin{array}{l}\text { Jakub, United } \\
\text { States, } \\
2004 \S^{17}\end{array}$ & $\begin{array}{l}\text { Medical } \\
\text { records }\end{array}$ & $\begin{array}{l}\text { Medical } \\
\text { records }\end{array}$ & NSABP & $\begin{array}{l}\text { Women treated for } \\
\text { breast cancer at } \\
\text { same hospital as } \\
\text { implant patients }\end{array}$ & $\begin{array}{l}76 \text { women: } \\
\text { localized 45; } \\
\text { non-localized 28; } \\
\text { unknown } 3\end{array}$ & $\begin{array}{l}4186 \text { women: } \\
\text { localized } 2758 ; \\
\text { non-localized 1352; } \\
\text { unknown } 76\end{array}$ & 14 & 49.5 & None \\
\hline $\begin{array}{l}\text { Pukkala, } \\
\text { Finland, } \\
2002^{19}\end{array}$ & $\begin{array}{l}\text { Medical } \\
\text { records }\end{array}$ & $\begin{array}{l}\text { Finnish } \\
\text { cancer } \\
\text { registry }\end{array}$ & SEER EOD & $\begin{array}{l}\text { General female } \\
\text { population with } \\
\text { breast cancer }\end{array}$ & $\begin{array}{l}7 \text { women: localized } \\
4 \text {; non-localized } 2 ; \\
\text { unknown } 1\end{array}$ & $\begin{array}{l}\text { Estimatesף: } \\
\text { localized 6.8; } \\
\text { non-localized } 4.8 \text {; } \\
\text { unknown } 0.9\end{array}$ & 8.3 & Unknown & $\begin{array}{l}\text { Standardized } \\
\text { for age at } \\
\text { diagnosis, } \\
\text { calendar period } \\
\text { of diagnosis }\end{array}$ \\
\hline $\begin{array}{l}\text { Deapen, } \\
\text { United } \\
\text { States, 2000 }\end{array}$ & $\begin{array}{l}\text { Plastic } \\
\text { surgeons' } \\
\text { records }\end{array}$ & $\begin{array}{l}\text { Cancer } \\
\text { registry }\end{array}$ & SEER EOD & $\begin{array}{l}\text { General female } \\
\text { population with } \\
\text { breast cancer }\end{array}$ & $\begin{array}{l}37 \text { women: in situ } \\
5 ; \text { localized } 19 ; \\
\text { non-localized } 13\end{array}$ & $\begin{array}{l}\text { External ratef: in } \\
\text { situ } 3.8 \text {; localized } \\
18.5 ; \text { non-localized } \\
14.6\end{array}$ & 12.2 & 50.3 & $\begin{array}{l}\text { Standardized } \\
\text { for age; } \\
\text { restricted to } \\
\text { white women }\end{array}$ \\
\hline $\begin{array}{l}\text { Brinton, } \\
\text { United } \\
\text { States, } \\
2000 \S^{21}\end{array}$ & $\begin{array}{l}\text { Plastic } \\
\text { surgeons' } \\
\text { records, self } \\
\text { administered } \\
\text { questionnaire }\end{array}$ & $\begin{array}{l}\text { Medical } \\
\text { records, } \\
\text { death } \\
\text { certificates }\end{array}$ & SEER EOD & $\begin{array}{l}\text { Women with other } \\
\text { cosmetic surgery } \\
\text { with breast cancer }\end{array}$ & $\begin{array}{l}78 \text { women: in situ } \\
\text { 12; localized } 32 ; \\
\text { non-localized } 27 \\
\text { unknown } 7\end{array}$ & $\begin{array}{l}36 \text { women: in situ } \\
\text { 10; localized } 19 ; \\
\text { non-localized } 6 ; \\
\text { unknown } 1\end{array}$ & 12.9 & 48 & None \\
\hline $\begin{array}{l}\text { Cahan, } \\
\text { United } \\
\text { States, } \\
1995 \S^{43}\end{array}$ & $\begin{array}{l}\text { Medical } \\
\text { records }\end{array}$ & $\begin{array}{l}\text { Medical } \\
\text { records }\end{array}$ & - & $\begin{array}{l}\text { Women treated for } \\
\text { breast cancer at } \\
\text { same institution as } \\
\text { implant patients }\end{array}$ & $\begin{array}{l}22 \text { women: } \\
\text { localized 13; } \\
\text { non-localized } 7 ; \\
\text { unknown } 2\end{array}$ & $\begin{array}{l}611 \text { women: } \\
\text { localized 473; } \\
\text { non-localized } 138\end{array}$ & 10 & - & None \\
\hline
\end{tabular}


Table 1 (continued)

\begin{tabular}{|c|c|c|c|c|c|c|c|c|c|}
\hline $\begin{array}{l}\text { First author, } \\
\text { country, } \\
\text { year }\end{array}$ & $\begin{array}{l}\text { Source of data } \\
\text { on implants }\end{array}$ & $\begin{array}{l}\text { Source of } \\
\text { data on } \\
\text { breast } \\
\text { cancer }\end{array}$ & $\begin{array}{l}\text { Assessment } \\
\text { of stage of } \\
\text { breast } \\
\text { cancer }\end{array}$ & Comparison group & $\begin{array}{l}\text { Women with } \\
\text { breast implants } \\
\text { with breast } \\
\text { cancer }\end{array}$ & $\begin{array}{l}\text { Women without } \\
\text { breast implants } \\
\text { with breast cancer }\end{array}$ & $\begin{array}{c}\text { Mean } \\
\text { length of } \\
\text { follow-up } \\
\text { (years) }^{*}\end{array}$ & $\begin{array}{l}\text { Average } \\
\text { age at } \\
\text { breast } \\
\text { cancer } \\
\text { diagnosis } \\
\text { (years) } \dagger\end{array}$ & Adjustment \\
\hline $\begin{array}{l}\text { Clark, United } \\
\text { States, } \\
1993 \S^{38}\end{array}$ & $\begin{array}{l}\text { Medical } \\
\text { records }\end{array}$ & $\begin{array}{l}\text { Medical } \\
\text { records }\end{array}$ & AJCC TNM & $\begin{array}{l}\text { Women diagnosed } \\
\text { as having breast } \\
\text { cancer and identified } \\
\text { in same breast } \\
\text { cancer registry as } \\
\text { implant patients }\end{array}$ & $\begin{array}{l}33 \text { women: } \\
\text { localized 25; } \\
\text { non-localized 6; } \\
\text { unknown } 2\end{array}$ & $\begin{array}{l}1735 \text { women: } \\
\text { localized } 1024 ; \\
\text { non-localized } 711\end{array}$ & - & 43 & None \\
\hline $\begin{array}{l}\text { Birdsell, } \\
\text { Canada, } \\
1993 \S^{40}\end{array}$ & $\begin{array}{l}\text { Health } \\
\text { insurance } \\
\text { claims, medical } \\
\text { records }\end{array}$ & $\begin{array}{l}\text { Alberta } \\
\text { cancer } \\
\text { registry }\end{array}$ & $\begin{array}{l}\text { AJCC TNM, } \\
\text { 4th edition }\end{array}$ & $\begin{array}{l}\text { General female } \\
\text { population with } \\
\text { breast cancer }\end{array}$ & $\begin{array}{l}41 \text { women: } \\
\text { localized 25; } \\
\text { non-localized 13; } \\
\text { unknown } 3\end{array}$ & $\begin{array}{l}13246 \text { women: } \\
\text { localized } 2172 ; \\
\text { non-localized } 1084 ; \\
\text { unknown } 9990\end{array}$ & 7.5 & $\begin{array}{c}45.7 \\
\text { (range } \\
30-68)\end{array}$ & None \\
\hline
\end{tabular}

AJCC TNM=American Joint Committee on Cancer, tumor node metastasis classification; NSABP=National Surgical Adjuvant Bowel Project; SEER EOD=surveillance epidemiology and end results summary stage system.

*Mean length of follow-up between date of breast implantation and earliest of diagnosis of breast or any other cancer, date of death, or end of follow-up period. †Average age at diagnosis of breast cancer among women with breast implants.

$\ddagger$ Adjusted odds ratio obtained by corresponding author of this paper.

§Crude odds ratio calculated using data in paper.

I Expected cases estimated on basis of information in paper. 
Table 2| Random effects overall odds ratio for association between cosmetic breast implants and stage distribution of breast cancer at diagnosis stratified by variables potentially related to study quality

\begin{tabular}{|c|c|c|c|}
\hline Stratification variable & No of studies & Overall effect-odds ratio $(95 \% \mathrm{Cl})$ & Meta-regression (P value) \\
\hline \multicolumn{4}{|l|}{ Source of comparison group: } \\
\hline Other non-augmented controls & 9 & 1.16 (0.88 to 1.53$)$ & \multirow[t]{2}{*}{0.33} \\
\hline Other cosmetic surgery controls & 3 & 1.53 (0.89 to 2.64$)$ & \\
\hline \multicolumn{4}{|l|}{ Breast cancer staging system†: } \\
\hline SEER EOD & 4 & 1.11 (0.58 to 2.13$)$ & \multirow[t]{2}{*}{0.87} \\
\hline AJCC TNM & 6 & $1.21(0.86$ to 1.71$)$ & \\
\hline \multicolumn{4}{|c|}{ Adjustment for potential confounders: } \\
\hline Adjusted & 5 & 1.51 (1.18 to 1.92$)$ & \multirow[t]{2}{*}{0.27} \\
\hline Unadjusted & 7 & $1.07(0.74$ to 1.55$)$ & \\
\hline \multicolumn{4}{|l|}{ Source of exposure data: } \\
\hline Medical records & 8 & $1.18(0.88$ to 1.59$)$ & \multirow[t]{2}{*}{0.53} \\
\hline Plastic surgeons' records & 4 & 1.39 (0.86 to 2.23$)$ & \\
\hline Year of publication & 12 & $0.03 \ddagger(0.00$ to 0.07$)$ & 0.06 \\
\hline
\end{tabular}

AJCC TNM=American Joint Committee on Cancer, tumor node metastasis classification; SEER EOD=surveillance epidemiology and end results summary stage system.

*Statistical significance for meta-regression model.

†Two studies were not included in this analysis.

$\ddagger$ Slope for model including year of publication as continuous variable. 
Table 3| Characteristics of five studies selected for quantitative analysis to evaluate association between cosmetic breast implants and breast cancer specific survival following breast cancer diagnosis

\begin{tabular}{|c|c|c|c|c|c|c|c|c|}
\hline $\begin{array}{l}\text { First author, } \\
\text { country, year }\end{array}$ & $\begin{array}{l}\text { Source of data } \\
\text { on breast } \\
\text { cancer }\end{array}$ & $\begin{array}{l}\text { Source of data } \\
\text { on mortality }\end{array}$ & Reference group & $\begin{array}{l}\text { Women with breast } \\
\text { implants and breast } \\
\text { cancer with survival } \\
\text { probability }\end{array}$ & $\begin{array}{l}\text { Women without } \\
\text { breast implants with } \\
\text { breast cancer with } \\
\text { survival probability }\end{array}$ & $\begin{array}{l}\text { Mean } \\
\text { follow-up } \\
\text { after } \\
\text { diagnosis } \\
\text { (years) }^{*}\end{array}$ & $\begin{array}{l}\text { Average age } \\
\text { at breast } \\
\text { cancer } \\
\text { diagnosis } \\
\text { (years) } \dagger\end{array}$ & Adjustment \\
\hline $\begin{array}{l}\text { Lavigne, } \\
\text { Canada, } \\
2012 \ddagger^{18}\end{array}$ & $\begin{array}{l}\text { Canadian cancer } \\
\text { registry, medical } \\
\text { records }\end{array}$ & $\begin{array}{l}\text { Canadian } \\
\text { mortality } \\
\text { database }\end{array}$ & $\begin{array}{l}\text { Women with other } \\
\text { cosmetic surgery } \\
\text { diagnosed as } \\
\text { having breast } \\
\text { cancer }\end{array}$ & $\begin{array}{l}400 \text { women: } 98.0 \% \\
\text { at } 1 \text { year; } 86.5 \% \text { at } 5 \\
\text { years; } 77.2 \% \text { at } 10 \\
\text { years }\end{array}$ & $\begin{array}{l}434 \text { women: } 99.1 \% \text { at } \\
1 \text { year; } 90.7 \% \text { at } 5 \\
\text { years; } 83.5 \% \text { at } 10 \\
\text { years }\end{array}$ & $\begin{array}{c}7.7 \text { (range } \\
0.1-31.9 \text { ) }\end{array}$ & $\begin{array}{l}52.3 \text { (range } \\
25-85)\end{array}$ & $\begin{array}{l}\text { Adjusted for } \\
\text { age at } \\
\text { diagnosis, } \\
\text { period of } \\
\text { diagnosis, and } \\
\text { province of } \\
\text { residence }\end{array}$ \\
\hline $\begin{array}{l}\text { Handel, United } \\
\text { States, } 2007 \S^{8}\end{array}$ & Medical records & Medical records & $\begin{array}{l}\text { Women treated } \\
\text { for breast cancer } \\
\text { at same clinics as } \\
\text { implant patients }\end{array}$ & $\begin{array}{l}120 \text { women: } 99.0 \% \\
\text { at } 1 \text { year; } 90.5 \% \text { at } 5 \\
\text { years }\end{array}$ & $\begin{array}{l}3922 \text { women: } 99.5 \% \\
\text { at } 1 \text { year; } 92.5 \% \text { at } 5 \\
\text { years }\end{array}$ & $\begin{array}{c}10.5 \text { (range } \\
0.5-37.0)\end{array}$ & $\begin{array}{l}46.8 \text { (range } \\
29-71)\end{array}$ & - \\
\hline $\begin{array}{l}\text { Holmich, } \\
\text { Denmark, } \\
2003 \S \mathbb{q}^{39}\end{array}$ & $\begin{array}{l}\text { Danish cancer } \\
\text { registry, hospital } \\
\text { records }\end{array}$ & $\begin{array}{l}\text { Danish cancer } \\
\text { registry }\end{array}$ & $\begin{array}{l}\text { General female } \\
\text { population } \\
\text { diagnosed as } \\
\text { having breast } \\
\text { cancer }\end{array}$ & $\begin{array}{l}23 \text { women: } 95.5 \% \text { at } \\
1 \text { year; } 86.0 \% \text { at } 5 \\
\text { years }\end{array}$ & $\begin{array}{l}253 \text { women: } 97.0 \% \text { at } \\
1 \text { year; } 78.0 \% \text { at } 5 \\
\text { years }\end{array}$ & $\begin{array}{l}6.4 \text { (range } \\
0.3-15.7 \text { ) }\end{array}$ & $\begin{array}{c}47.2^{\star \star} \text { (range } \\
35-75)\end{array}$ & - \\
\hline $\begin{array}{l}\text { Deapen, } \\
\text { United States, } \\
2000 \S^{41}\end{array}$ & $\begin{array}{l}\text { Plastic surgeons' } \\
\text { records, cancer } \\
\text { registry }\end{array}$ & $\begin{array}{l}\text { Cancer registry, } \\
\text { National Center } \\
\text { for Health } \\
\text { Statistics, death } \\
\text { certificates }\end{array}$ & $\begin{array}{l}\text { General female } \\
\text { population }\end{array}$ & $\begin{array}{l}37 \text { women: } 94.6 \% \text { at } \\
1 \text { year; } 88.5 \% \text { at } 5 \\
\text { years }\end{array}$ & $\begin{array}{l}\text { External rate: } 97.9 \% \\
\text { at } 1 \text { year; } 84.1 \% \text { at } 5 \\
\text { years }\end{array}$ & $\begin{array}{c}6.6 \text { (range } \\
0.2-17.3 \text { ) }\end{array}$ & 50.3 & $\begin{array}{l}\text { Standardized } \\
\text { for age at } \\
\text { diagnosis, } \\
\text { stage at } \\
\text { diagnosis, and } \\
\text { years of } \\
\text { diagnosis }\end{array}$ \\
\hline $\begin{array}{l}\text { Birdsell, } \\
\text { Canada, } \\
1993 \S^{40}\end{array}$ & $\begin{array}{l}\text { Health insurance } \\
\text { claims, Alberta } \\
\text { cancer registry, } \\
\text { medical records }\end{array}$ & $\begin{array}{l}\text { Alberta cancer } \\
\text { registry }\end{array}$ & $\begin{array}{l}\text { General female } \\
\text { population }\end{array}$ & $\begin{array}{l}41 \text { women: } 94.0 \% \text { at } \\
1 \text { year; } 83.0 \% \text { at } 5 \\
\text { years; } 73.0 \% \text { at } 10 \\
\text { years }\end{array}$ & $\begin{array}{l}13246 \text { women: } \\
96.0 \% \text { at } 1 \text { year; } \\
74.0 \% \text { at } 5 \text { years; } \\
62.0 \% \text { at } 10 \text { years }\end{array}$ & $\begin{array}{c}10.2 \text { (range } \\
1.0-18.0 \text { ) }\end{array}$ & $\begin{array}{c}45.7 \text { (range } \\
30-68)\end{array}$ & - \\
\hline
\end{tabular}

*Length of interval between date of diagnosis of breast cancer and earliest of date of death from breast cancer or end of the follow-up period among women with breast implants.

†Average age at diagnosis of breast cancer among women with breast implants.

$\ddagger$ Hazard ratio adjusted for age at diagnosis, period of diagnosis, and province provided in paper.

$\S$ Hazard ratio calculated using data in paper.

IAssessed overall mortality.

${ }^{\star \star}$ Average age at breast cancer diagnosis among both implant patients and comparison group. 


\section{Figures}

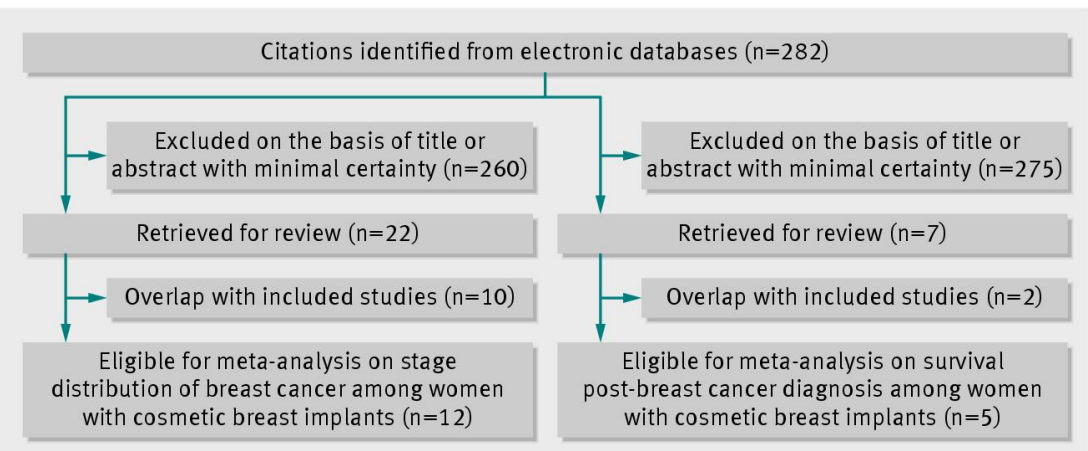

Fig 1 Flow chart of meta-analysis search strategy and process of selecting articles on association between cosmetic breast implants and stage distribution of breast cancer and association between cosmetic breast implants and survival after diagnosis of breast cancer

Study

Birdsell et al $1993^{40}$ Clark et al $1993^{38}$ Cahan et al $1995^{43}$ Deapen et al $2000^{41}$ Brinton et al $2000^{21}$ Pukkala et al $2001^{19}$ Jakub et al $2004^{17}$ Miglioretti et al $2004^{42}$ Friis et al $2005^{15}$ Tuli et al $2006^{13}$ Handel et al $2007^{8}$ Lavigne et al $2012^{18}$ Total: $P=0.106,\left.\right|^{2}=35.6 \%$

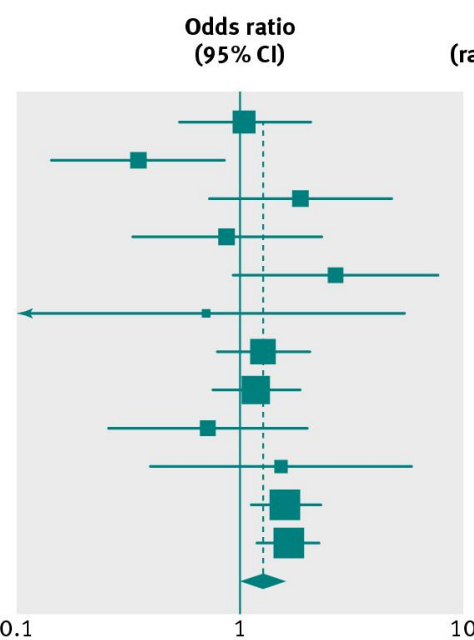

Weight (\%) Odds ratio (random effects $\quad(95 \% \mathrm{Cl})$ analysis)

$8.56 \quad 1.04$ (0.53 to 2.04)

5.590 .35 (0.14 to 0.85 )

$5.17 \quad 1.86$ ( 0.73 to 4.76 )

$4.85 \quad 0.87$ (0.33 to 2.30 )

$4.31 \quad 2.67$ (0.93 to 7.64 )

$1.28 \quad 0.70$ (0.09 to 5.43 )

$13.07 \quad 1.27$ (0.79 to 2.04 )

$14.02 \quad 1.17$ (0.75 to 1.83 )

$4.49 \quad 0.71$ (0.26 to 1.99)

$2.77 \quad 1.52$ (0.39 to 5.88 )

$17.08 \quad 1.59$ (1.11 to 2.27 )

$18.82 \quad 1.65$ (1.21 to 2.25 )

$100.00 \quad 1.26$ (0.99 to 1.60$)$

Fig 2 Forest plot with study specific and random effects overall odds ratio for association between cosmetic breast implants and stage distribution of breast cancer at diagnosis (dichotomized as non-localized (regional or distant) versus localized breast cancer)

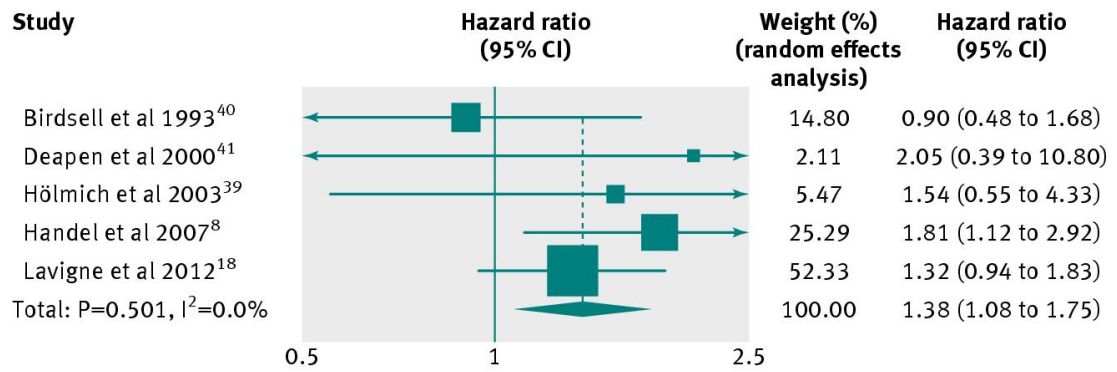

Fig 3 Forest plot with study specific and random effects overall hazard ratio for association between cosmetic breast implants and breast cancer specific survival 